\title{
Dung removal by dung beetles (Coleoptera: Scarabaeidae) and macrocyclic lactone use on cattle ranches of Yucatan, Mexico
}

\author{
Gertrudis S. Basto-Estrella ${ }^{1}$, Roger I. Rodríguez-Vivas ${ }^{1}$, Hugo Delfín-González ${ }^{1}$, Jorge A. \\ Navarro-Alberto ${ }^{1}$, Mario E. Favila ${ }^{2} \&$ Enrique Reyes-Novelo ${ }^{3 *}$ \\ 1. Campus de Ciencias Biológicas y Agropecuarias. Universidad Autónoma de Yucatán. Carretera Mérida-Xmatkuil \\ Km 15.5, A.P 116. C. P. 97315. México. Mérida, Yucatán; gertrudisbasto@hotmail.com, rvivas@correo.uady.mx, \\ gdelfin@correo.uady.mx, jorge.navarro@correo.uady.mx \\ 2. Instituto de Ecología, A.C. Carretera antigua a Coatepec 351. El Haya. C. P. 91070. México. Xalapa, Veracruz; \\ mario.favila@inecol.mx \\ 3. Centro de Investigaciones Regionales “Dr. Hideyo Noguchi”. Universidad Autónoma de Yucatán. Av. Itzaes No. 490 \\ x 59. C. P. 97000. México. Mérida, Yucatán; enrique.reyes@correo.uady.mx \\ * Correspondence
}

Received 21-IX-2015. C Corrected 20-IV-2016. Accepted 20-V-2016.

\begin{abstract}
The expanded use of macrocyclic lactones (ML) to treat endo- and ectoparasites in cattle in tropical regions, can reduce dung beetle populations, and thus interrupt the dung removal process in cattle pasture ecosystems. During the reproductive period (the rainy season) of two functional groups of dung beetles (paracoprid and telocoprid Scarabaeinae), we compared dung removal amount in ranches where ML are and are not used in Yucatan, Mexico, through exclusion traps baited with $500 \mathrm{~g}$ of ML-free cow dung. On each ranch, two transects (separated by $500 \mathrm{~m}$ ) with six traps each, were set up for 24 hours. After this time, all the dung remnants in each trap were obtained and weighed in order to record the dung removal. Results showed that dung removal amounts were similar in ranches with and without ML use. Dung beetles removed $40.1 \%$ of all cow dung weighed. Paracoprids removed $87.46 \%$ and telocoprids $12.54 \%$ of all the dung that was removed. Our results indicated that the ecological function of dung beetles in the pastures studied, does not seem to be affected by the ML use, and that paracoprid species removed most of the dung. For both types of ranch, further studies that take into account the population dynamics and movement of the most important dung beetle species in the region are required, coupled with laboratory studies evaluating the effect of ML on their reproductive success. This could give some light on the effect of ML on the ecological function of this important insect group in the sustainability of cattle production systems. Rev. Biol. Trop. 64 (3): 945-954. Epub 2016 September 01.
\end{abstract}

Key words: ivermectin, paracoprid, telocoprid, pastureland.

Cattle dung is an abundant resource in ranch pastures (Wall \& Beynon, 2012). In temperate and tropical areas, a large part of the dung removal from the ground is done by dung beetles belonging to the subfamily Scarabaeinae (Floate, 2011). Dung removal accelerates the incorporation of dung nutrients into the soil, contributing to natural fertilization, maintaining grassland productivity, favoring bioturbation (the mixing of soil and sediment particles by animals or plants), and controlling natural cattle pests such as gastrointestinal nematodes and hematophagous flies; furthermore, the dung beetles act as secondary seed dispersers (Andresen \& Feer, 2005; Nichols et al., 2008). Dung beetles therefore provide ecological benefits to cattle production systems (Halffter \& Edmonds, 1982; Hanski \& Cambefort, 1991); these benefits have been calculated to have an annual value of ca 380 million dollars in the USA (Losey \& Vaughan, 2006).

In natural environments, Scarabaeinae species compete for dung and have developed different strategies to obtain this resource for 
nesting and feeding. According with the dung relocation strategy, dung beetles are divided into tunnelers (paracoprids), rollers (telocoprids), and dwellers (endocoprids) (Halffter \& Edmonds, 1982; Hanski \& Cambefort, 1991). Paracoprid beetles dig straight or branched tunnels below or beside the dung source, where they store the dung for consumption or reproduction. Telocoprid beetles cut a small portion of dung that is transformed into a food ball that is rolled to a certain distance by an individual or by a male-female pair, and it is then buried just below the soil surface. This is consumed by a beetle, or transformed in a brood ball where the female deposits an egg. Endocoprid beetles feed directly on the dung and do not relocate the food, and so are less important in the dung removal process in tropical regions, in terms of the amount of dung removed (Halffter \& Edmonds, 1982).

Both paracoprid and telocoprid dung beetles actively participate in cattle dung recycling, favoring the productivity of pastures (Nichols et al., 2008), but their assemblages are threatened by the macrocyclic lactones (ML) used to treat endo- and ectoparasites in cattle (Floate, 2011). Residues of ML, particularly ivermectin, are excreted in dung and there is increasing evidence of their lethal and sublethal effects on the immature stages (eggs and larvae) of dung beetle species (Errouissi \& Lumaret, 2010; Floate, 2011; Wall \& Beynon, 2012; Webb, Beaumont, Nager, \& McCracken, 2010). The intensive use of ML to treat parasites in cattle can lead to drastic reductions in Scarabaeinae population abundance, especially if this type of endectocide is used during the beetle reproduction period, when eggs and larvae are exposed to the chemical compound (Errouissi \& Lumaret, 2010). Dung beetle population decline, may alter the ecological services provided by this group of insects, reducing the sustainability of cattle ranching (Dadour, Cook, \& Neesam, 1999; Lee \& Wall, 2006; Steinfeld et al., 2006; Wall \& Strong, 1987).

A recent study in a cattle ranching region in the state of Yucatan (Mexico), found that in pastures where cattle were treated with ML
(ML sites), dung beetle community diversity was lower than in pastures that were not treated (non-ML sites) (Basto-Estrella, RodríguezVivas, Delfín-González, \& Reyes-Novelo, 2014). Similarly, the composition and structure of the dung beetle assemblage were altered in pastures where cattle were treated with ML, and abundance was higher in ML sites than in non-ML sites (Basto-Estrella et al., 2014). The highest dung beetle abundance in the area was recorded in the middle of the rainy season (July) (Basto-Estrella, Rodríguez-Vivas, Delfín-González, \& Reyes-Novelo, 2012). The objective of the present study was to evaluate dung removal amount by dung beetles on ranches where ML are used and those where ML are not used to treat endo- and ectoparasites in cattle. Dung removal was compared between both types of ranches at the beginning, in the middle and at the end of the rainy season, when dung beetle richness and abundance were the highest in the region (Basto-Estrella et al., 2012; Reyes-Novelo, Delfín-González, \& Morón-Ríos, 2007). If the behavior and biology of dung beetles in ML sites is negatively affected by the endectocide (Errouissi \& Lumaret, 2010; Floate, 2011; Wall \& Beynon, 2012; Webb, Beaumont, Nager, \& McCracken, 2010), we hypothesize that the quantity of removed dung will be higher in non-ML sites than in ML using sites. Additionally, we hypothesize that tunneler beetles should remove more dung than telocoprid beetles at sites level, and that the maximum dung removal is expected to occur in the middle of the rainy season in accordance with the abundance of these beetles reported by Basto-Estrella et al. (2012).

\section{MATERIALS AND METHODS}

Study site: The study was conducted in Tizimin, Yucatan, Mexico (21 ${ }^{\circ} 36^{\prime} \mathrm{N}-88^{\circ} 16^{\prime}$ W) during three months of the regional rainy season in 2011: May $\left(29{ }^{\circ} \mathrm{C}, 7.8 \mathrm{~mm}\right)$, July $\left(27.8{ }^{\circ} \mathrm{C}, 288.7 \mathrm{~mm}\right)$, and October $\left(24.6{ }^{\circ} \mathrm{C}\right.$, $146.3 \mathrm{~mm}$ ). Tizimin is the primary cattle producing area of Yucatan, and ML is frequently used to control endo- and ectoparasites on 
cattle, though these compounds are not used in all ranches. The region's climate is warm subhumid, with $1000 \mathrm{~mm}$ average annual rainfall, and an average annual temperature of $25.8{ }^{\circ} \mathrm{C}$. Geomorphology in the region corresponds to a young Karst tectonic system, classified as an undulating structural plain with dissolution and denudation, where characteristic soils are Lithosol, Rendzine and Cambisol, at an approximated altitude of 20 masl (Bautista-Zúñiga, Batllori, Palacio, Ortiz, \& Castillo, 2005).

The field study was conducted on two ranches where ML are used on cattle (Pedregal and San Carlos) and two where ML were not used (Actun Ha and Santa Rosa), though other types of anti-parasitic methods were in use (Table 1). All four ranches are surrounded by secondary vegetation of tropical deciduous forest (Ramírez-Cancino \& Rivera-Lorca, 2010) and the ranches were separated by a distance among 35 to $40 \mathrm{~km}$. A semi-intensive livestock production system is used in all ranches, based on year-round grazing on improved pastures planted with Brachiaria brizantha (Hochst. Ex A. Rich.) and Panicum maximum (Jacq.) (B.K. Simon \& S.W.L. Jacobs); supplemental feed is given to cattle during the dry season (February to April). Herds had 79 to 249 head of Bos indicus L. $\mathrm{x}$ B. taurus L. on each ranch. Gastrointestinal nematodes and ticks are common parasites in the region (Canul-Ku et al., 2012).
At the Actun-Ha and Santa Rosa ranches ML had never been used to control parasites prior to the study, but other types of anti-parasitic drugs are being used (Table 1). At the San Carlos and Pedregal ranches Ivermectin ( $1 \%, 0.2$ $\mathrm{mg} / \mathrm{kg}$ subcutaneous) is commonly applied to at least $70 \%$ of the existing herd, including calves, weaners, bulls and heifers. At Pedregal, Ivermectin had been applied two to three times a year during the three years prior to the study, while at San Carlos Ivermectin had been applied three to four times a year during the five years prior to the study (Table 1).

Scarabaeinae assemblage composition in studied ranches: In previous studies, we describe the Scarabaeinae composition founded in the four sampled ranches (BastoEstrella et al., 2012, 2014). The species richness was between 13 to 17 species per ranch (Basto-Estrella et al., 2012, 2014). Ten were paracoprids and seven were telocoprids. BastoEstrella et al. (2014) found that paracoprids were almost two times more abundant than telocoprids (60 417 vs. 32857 individuals, respectively). The paracoprid Onthophagus landolti Harold was the dominant species (61 $\%$ of total abundance), and the telocoprid Canthon indigaceus chevrolati LeConte was the second most important species. Ranches where ML was used had lower species richness (15) and lower diversity (1.39 times less)

TABLE 1

Ranch size, herd size, stocking density, and anti-parasitic drugs used to control endo- and ectoparasites on cattle at the four ranches studied in the Yucatan, Mexico

\begin{tabular}{|c|c|c|c|c|c|c|}
\hline Ranch & Area (ha) & $\begin{array}{c}\text { Number of bovines } \\
\text { in the Herd }\end{array}$ & $\begin{array}{l}\text { Stocking density } \\
\text { (bovine/ha) }\end{array}$ & $\begin{array}{l}\text { Anti-parasitic } \\
\text { drug used }\end{array}$ & $\begin{array}{l}\text { Anti-parasitic } \\
\text { family }\end{array}$ & $\begin{array}{c}\text { Time of use } \\
\text { per year }\end{array}$ \\
\hline Actun-Ha & 80 & 70 & 1.1 & $\begin{array}{l}\text { Ricobendazle } \\
\text { Levamisole } \\
\text { Amitraz } \\
\text { Coumaphos }\end{array}$ & $\begin{array}{l}\text { Albendazole } \\
\text { Imidazothiazole } \\
\text { Amidine } \\
\text { Organophosphate }\end{array}$ & $\begin{array}{c}1 \\
1 \\
4-5 \\
1-2\end{array}$ \\
\hline Santa Rosa & 70 & 70 & 1.0 & $\begin{array}{l}\text { Levamisole } \\
\text { Amitraz } \\
\text { Coumaphos }\end{array}$ & $\begin{array}{l}\text { Imidazothiazole } \\
\text { Amidine } \\
\text { Organophosphate }\end{array}$ & $\begin{array}{c}1 \\
4-5 \\
2-3\end{array}$ \\
\hline Pedregal & 90 & 87 & 1.0 & $\begin{array}{l}\text { Ivermectin } 1 \% \\
\text { Amitraz }\end{array}$ & $\begin{array}{l}\text { Macrocyclic lactone } \\
\text { Amidine }\end{array}$ & $\begin{array}{l}2-3 \\
5-6\end{array}$ \\
\hline San Carlos & 269 & 249 & 1.0 & $\begin{array}{l}\text { Ivermectin } 1 \% \\
\text { Amitraz }\end{array}$ & $\begin{array}{l}\text { Macrocyclic lactone } \\
\text { Amidine }\end{array}$ & $\begin{array}{l}3-4 \\
4-5\end{array}$ \\
\hline
\end{tabular}


than ranches that did not use ML (17) (BastoEstrella et al., 2014).

Study design and data analysis: Dung removal amount per dung beetle functional group were evaluated for both types of sites. Exclusion traps (Slade, Mann, Villanueva, \& Lo, 2007) were modified (mainly in the dimensions to $35 \mathrm{~cm}$ in diameter and $18 \mathrm{~cm}$ of height) and builted using $1 \mathrm{~mm}^{2}$ steel mesh with a 10 $\mathrm{cm}$ diameter hole in the bottom. These dispositives allowed the quantification of the amount of excrement that telocoprid and paracoprid beetles removed. Each exclusion trap was laid on the soil and $500 \mathrm{~g}$ of ML-free cattle dung was placed in the hole as bait. Prior to the experiments, the dung used was frozen for 48 hours to eliminate any coprophile insects. On each ranch two transects (separated by 500 m) with six traps each were installed. Exclusion traps were placed $200 \mathrm{~m}$ apart along each transect. Three exclusion traps were used to measure dung removal by dung beetles, and the other three exclusion traps were completely enclosed (with no hole in the bottom) to measure dung weight loss from dehydration. The amount of dung (in grams) removed by the two functional groups was quantified after $24 \mathrm{~h}$ by subtracting the weight loss owing to dehydration and the weight of the dung remaining in the trap from the original 500 $\mathrm{g}$ bait weight. The weight of dung removed from the bait but left in the trap as food balls, constructed and rolled by telocoprids, was subtracted from the resulting data to calculate the dung weight removed by paracoprids. All dung weight measures were performed with an analytical scale ( $0.1 \mathrm{~g}$ of capacity) at the laboratory. The remains of excrement recovered from the traps were placed in plastic bags with hermetic seal and weighted. The bag's weight was standardized previously for subtraction from the final weight.

Dung removal between the ML sites and non-ML sites over time was compared separately for each functional group. Each trap represented a "subject" (in the terminology used in repeated measures design) since removal activity by each functional group was measured at the traps over three periods during the rainy season (May, July and October, corresponding to the beginning, middle and end of the rainy season, respectively). Therefore, time, the within-subject factor, was treated as a fixed factor with three levels. The experimental factor (ranch) is a random factor nested within the "condition" factor. Similarly, "transect" is a random factor nested within "ranch", with two levels per ranch. The resulting model for this design and each functional group is: $y_{m(i j k l)}=\mu+\alpha_{i}+\tau_{j}+(\alpha \tau)_{i j}+r_{k(i)}+t_{l(k)}+e_{m(i j k l) \text {, where }}$ $y_{m(i j k l)}$ is the amount of dung removed (in grams) by each functional group, from trap $m$ located on transect $l$, on ranch $k$ with condition $i$, at time $j, i=1,2 ; j=1,2,3 ; k=1,2 ; l=1,2 ; m=$ $1,2,3 ; \mu$ is the total average removal, $\alpha_{i}$ is the fixed effect of condition $i, \tau_{j}$ the fixed effect of time $j,(\alpha \tau)_{i j}$ is the interaction of condition $i$ and time $j, r_{k(i)}$ is the random effect of ranch $k$ on condition $i, t_{l(k)}$ is the random effect of transect $l$ on ranch $k$, and $e_{m(i j k l)}$ is the random error effect of trap $m$ on transect $l$, on ranch $k$ with condition $i$, at time $j$. Given the large distance between traps within each transect, these random errors were assumed to be independent for each sampling event, although there may be some correlation from repeated measurements of the same trap.

The amount of dung removed between ML conditions was compared using the mixed model with repeated measures defined above. The random or residual errors associated with the three periods of observations made at each trap (i.e. May, July and October) were assumed to follow a normal multivariate distribution: $\mathbf{e}_{m}=\mathbf{e}_{m(\ldots)} \sim N\left(\mathbf{0}, \mathbf{R}_{m}\right)$ where $\mathbf{R}_{m}$ is a $3 \times 3$ covariance matrix. To establish the possible structures of the $\mathbf{R}_{m}$ covariance, the fact that the months when dung removal was measured are not evenly spaced was taken into account. The structure reaching the minimum corrected Akaike Information Criterion (AICc) was chosen as the working covariance structure in the significance tests of the fixed effects. Residuals were analyzed to identify possible violations of the normality assumption. Data 
were $\log$ transformed when needed to produce approximately normal residuals. Fixed effects were tested at the $\alpha=0.05$ significance level. All calculations were run using the SAS 9.2/ MIXED ${ }^{\circledR}$ procedure (Littell, Milliken, Stroup, Wolfinger, \& Schabenberger, 2006).

\section{RESULTS}

At $24 \mathrm{~h}, 61.86 \%(22259.9 \mathrm{~g})$ of the initial dung weight was lost, but $21.73 \%$ $(7822.8 \mathrm{~g})$ of this total was due to moisture loss. Weight loss from evaporation varied throughout the rainy season, and was highest early in the season (May), and lowest at the end of the season (October). The dung beetle assemblage was responsible for $40.1 \%$ (14 $437.1 \mathrm{~g})$ of dung weight loss, which varied little between months; nonetheless, total dung removed by beetles was lowest early in the season $(33.79 \%)$ and highest at the end of the season (44.05\%) (Table 2).

Paracoprids removed $87.46 \%$ (12626.3 g) and telocoprids $12.54 \%$ (1810.8 g) of the removed dung (Fig. 1). Endocoprids were not observed in the dung remains. Paracoprids

TABLE 2

Total dung removal in grams (and percentage) by the Scarabaeinae assemblage and weight loss by evaporation over a $24 \mathrm{~h}$ period at three times during the rainy season on four ranches in the Yucatan, Mexico

\begin{tabular}{lcccc} 
& $\mathrm{T}^{1}$ & $\mathrm{~T} 2^{2}$ & $\mathrm{~T}^{3}$ & Total \\
Dung removal by Scarabaeinae & $4054.4(33.79 \%)$ & $5097.2(42.48 \%)$ & $5285.5(44.05 \%)$ & $14437.1(40.10 \%)$ \\
Weight loss from evaporation & $4120.8(34.34 \%)$ & $2805.6(23.38 \%)$ & $896.4(7.47 \%)$ & $7822.8(21.73 \%)$ \\
Total weight loss & $8175.2(68.13 \%)$ & $7902.8(65.86 \%)$ & $6181.9(51.52 \%)$ & $22259.9(61.83 \%)$ \\
\hline
\end{tabular}

${ }^{1} \mathrm{~T} 1=$ early rainy season $\left(\right.$ May). ${ }^{2} \mathrm{~T} 2=$ mid-rainy season $(\mathrm{July}) .{ }^{3} \mathrm{~T} 3=$ late rainy season (October).

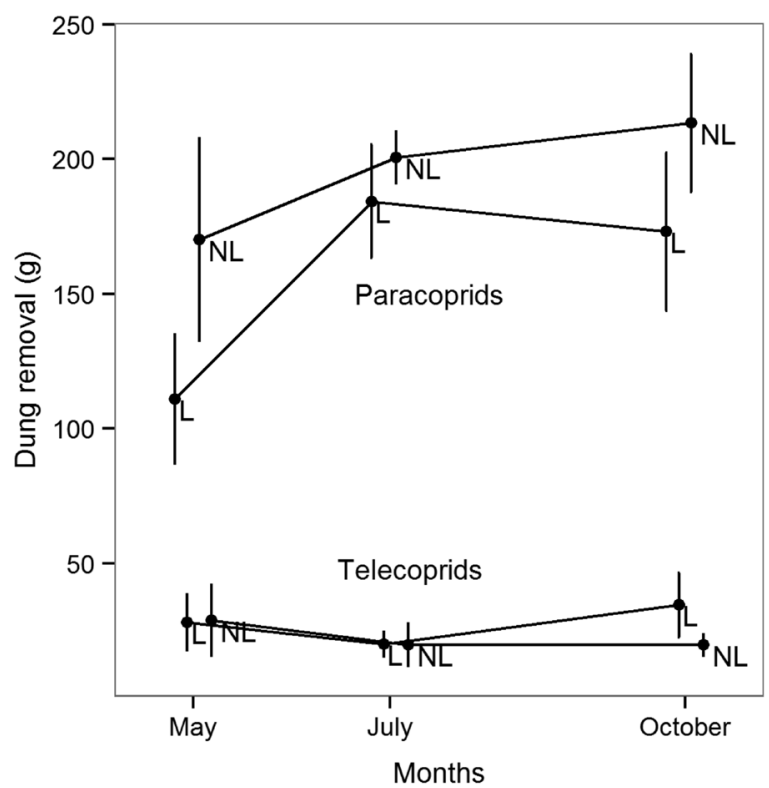

Fig. 1. Dung removal amounts of paracoprid and telocoprid functional groups of dung beetles on ranches with macrocyclic lactone use (L), and without macrocyclic lactone use (NL) to control endo- and ectoparasites on cattle during three sampling periods in the Yucatan, Mexico. Vertical lines represent mean \pm standard error. 
removed a higher proportion for all three sampling times and at both types of sites (ML sites and non-ML sites) (Table 3). No significant interaction was observed between ML sites and sampling times (paracoprids: $\mathrm{F}=0.28$, denominator $\mathrm{df}=\mathrm{df}_{\text {denom }}=44, \mathrm{P}=0.7539$; telocoprids, for $\log ($ removal $): \mathrm{F}=0.52, \mathrm{df}_{\text {denom }}=$ $44, \mathrm{P}=0.5977)$. The principal effects of these two factors were not significant (condition: $\mathrm{F}=$ 3.07, $\mathrm{df}_{\text {denom }}=44, \mathrm{P}=0.2217$ for paracoprids; $\mathrm{F}=0.04, \mathrm{df}_{\text {denom }}=44, \mathrm{P}=0.8668$ for telocoprids, based on $\log ($ removal $)$; Time: $\mathrm{F}=2.23, \mathrm{df}_{\text {de- }}$ ${ }_{\text {nom }}=44, \mathrm{P}=0.1195$ for paracoprids; $\mathrm{F}=2.05$, $\mathrm{df}_{\text {denom }}=44, \mathrm{P}=0.1411$ for telocoprids, using $\log ($ removal $))$. Most of the variation in the data was due to the traps' random variation, and the compound symmetry covariance structure fit the repeated measurements well (Table 4).

\section{DISCUSSION}

Our results confirm that cattle dung in tropical pastures can be completely buried and/ or relocated in a matter of hours due to the dominance of paracoprid and telocoprid dung beetles (Floate, 2011). In contrast, dung removal in temperate grasslands can take months or even years because the dominant dung beetles are endocoprids, which are characteristically smaller beetles and both feed and reproduce inside dung pads, meaning these pads remain on the surface for long periods of time (Halffter \& Edmonds, 1982).

In the pastures studied, endocoprids were not observed. The paracoprids were the dominant functional group and were responsible for a significantly greater proportion of dung removal. This is probably explained by their greater species richness (10 paracoprids vs. 7 telocoprids) at the ranches studied and the notable abundance of individuals (60417 paracoprids vs. 32857 telocoprids) (Basto-Estrella et al., 2012). Paracoprids have also been reported as the dominant functional group in the tropical forests of Africa (Slade, Mann, Villanueva, $\&$ Lo, 2007), and these authors also found that

TABLE 3

Total dung removed in grams (and percentage) by paracoprid and telocoprid functional groups in each of the cattle ranches where macrocyclic lactones are used (ML sites), and where they are not used (non-ML sites) to control endo- and ectoparasites on cattle at three sampling times in Yucatan, Mexico

\begin{tabular}{lcccc}
\multicolumn{1}{c}{ Functional group/condition } & $\mathrm{T}^{1}$ & $\mathrm{~T}^{2}$ & $\mathrm{~T}^{3}$ & Total \\
Telocoprids/ML sites & $345(8.51 \%)$ & $237.6(4.66 \%)$ & $235.9(4.46 \%)$ & $818.5(5.67 \%)$ \\
Telocoprids/Non-ML sites & $337.2(8.32 \%)$ & $241.2(4.73 \%)$ & $413.9(7.83 \%)$ & $992.3(6.87 \%)$ \\
Total telocoprids & $682.2(16.83 \%)$ & $478.8(9.39 \%)$ & $649.8(12.29 \%)$ & $1810.8(12.54 \%)$ \\
Paracoprids/ ML sites & $2041.9(50.36 \%)$ & $2406.9(47.22 \%)$ & $2559.7(48.43 \%)$ & $7008.5(48.55 \%)$ \\
Paracoprids/ Non-ML sites & $1330.3(32.81 \%)$ & $2211.5(43.39 \%)$ & $2076(39.28 \%)$ & $5617.8(38.91 \%)$ \\
Total paracoprids & $3372.2(83.17 \%)$ & $4618.4(90.61 \%)$ & $4635.7(87.71 \%)$ & $12626.3(87.46 \%)$ \\
\hline
\end{tabular}

${ }^{1} \mathrm{~T} 1=$ early rainy season (May). ${ }^{2} \mathrm{~T} 2=$ mid-rainy season $(\mathrm{July}) .{ }^{3} \mathrm{~T} 3=$ late rainy season (October).

TABLE 4

Estimates of variance parameters by ranch within sites (ML sites and non-ML sites), by transect within-ranch (two transect per ranch), and residual random effects, and estimates of the covariance parameters for the compound symmetry structure of repeated measures, in the mixed model of dung removal

\begin{tabular}{lcc}
\multicolumn{1}{c}{ Variance parameter } & Paracoprids (removal) & Telocoprids [log(removal)] \\
Ranch (condition) & 41.17 & 0.4191 \\
Transect (ranch) & 542.97 & 0.4636 \\
Residual & 9808.54 & 2.1784 \\
Covariance parameter for the compound symmetry & -2231.88 & -0.5786 \\
\hline
\end{tabular}


these two groups do not interfere with each other or compete, but rather complement one another, maximizing their contribution to maintaining the ecological functions of the system.

Species richness may be the easiest biodiversity component to measure, but different species do not have the same functions in natural communities and therefore do not contribute equally to all ecological functions (Chalcraft \& Resetarits, 2003 a, b; Loreau, 2004). Therefore, species richness, abundance and the specific ability of each species in the process of dung location and removal must be taken into consideration throughout the total dung removal since this has a natural variation and probably modified by the presence of ML in the dung (Flota-Bañuelos et al., 2012; Verdú et al., 2015). In a previous study in the same ranches, the dominant species $(61 \%$ of total abundance, $94.31 \%$ of paracoprid abundance) was $O$. landolti, a small diurnal paracoprid (Basto-Estrella et al., 2012). The differences in dung removal between the two functional groups were probably a result of the activity of this dominant species. This species represents the most functionally important dung beetle species in the pastures studied, not just because of its greater abundance, but also because it makes efficient use of large mammal excreta, as other Onthophagus species do (Davis \& Philips, 2005).

Dung removal was expected to be higher in the middle of the rainy season (July) because it coincides with the highest dung beetle abundance observed previously in the same area (Basto-Estrella et al., 2012). However, the quantity of dung removed did not significantly vary over time during the study period. Heavy rain promotes forage growth, which in turn increases cattle forage intake, and consequently dung production and deposition rates (Floate, 2011). This imply that dung beetle abundances were higher during this period but probably so was the amount of dung available, suggesting that beetle removal activity was distributed across the total dung masses, resulting in almost no change in the recorded removal amounts.
In previous studies of the same pastures (Basto-Estrella et al., 2012, 2014), the ML sites were found to have lower dung beetle species diversity and to experience changes in dung beetle assemblage composition, structure and abundance patterns. However, our results show that these changes were not still enough to alter dung removal amounts at the ML sites, compared to the non-ML sites. This helps us to better understand the relationship between the degree to which these species' contribution could be affected by ML, and the extent of any negative effect on pastures functioning. For example, the high abundance of the dominant species, O. landolti (Basto-Estrella et al., 2014), could maintain the ecological services of the dung beetle assemblage sufficiently well to mask the effect of the disturbance caused by ML use. Another possibility is that the pastures where ML are not used, may be acting as a source of healthy specimens that colonize pastures where ML are being used, and potentially reducing dung beetle populations.

Given the need for parasite control in the cattle industry, the collateral effect of ML on other species may seem acceptable to ranchers. However, these routine treatments still need to be analyzed because if used over the long term they may completely eliminate some species from the ecosystem, and cause severe damage to crucial ecosystem services, such as dung removal. The fact that we observed no change in dung removal amount in the present study does not mean that ML has no negative effect on dung beetle populations. The negative effects of ML on dung beetle species have been confirmed in laboratory studies, for several Old World species (Lumaret, Errouissi, Floate, Römbke, \& Wardhaugh, 2012; Wall \& Beynon, 2012; Verdú et al., 2015) and one new world species (Pérez-Cogollo, Rodríguez-Vivas, Delfín-González, Reyes-Novelo, \& Ojeda-Chi, 2015). And it is likely that field confirmation of the negative effects on dung beetle population requires a longer study period than that used here. Continued, intensive use of ML could gradually erode dung beetle diversity, with negative consequences for the functioning of 
pastures and the regional sustainability of cattle ranching. At the landscape scale, the functioning of the studied pasture system would be seriously affected if ML modifies the capacity of the most important species (v. gr. O. landolti) to fulfill its role in this ecosystem. This is critical since recent studies documented sublethal effects of ivermectin on $O$. landolti (PérezCogollo et al., 2015).

This is the first field study on how the use of ML affects the dung removal capacity of dung beetle communities in cattle pastures in the Mexican tropics. Further studies are required to more completely address this problem. Experimental studies in which the responses of the dominant species in pastures to controlled ML residue exposure are required. These studies should be coupled with monitoring studies to detect the potential movement of individuals across the landscape, and any reduction in dung beetle populations, as well as changes in dung removal amounts, mostly for cattle ranches where ML are used. This would make it possible to recommend mitigation measures, such as the promotion of alternative methods of parasite control in cattle and specific treatment schedules to prevent ecosystem deterioration.

\section{ACKNOWLEDGMENTS}

This research was financed by CONACYTMexico (Project No. 128870) and a scholarship granted to GBE. The authors thank the ranchers of Tizimin, Yucatan, for providing access to their properties. To Víctor Parra Tabla, Virginia Melendez, and Armando Aguilar Caballero for their comments on early versions of this manuscript. We thank Bianca Delfosse for linguistic corrections. We are grateful with Roberto Barrientos for his assistance with statistical analysis; and to Melina Ojeda-Chi, Joaquín Fernández, and Israel Chan Pérez for their assistance in fieldwork.

\section{RESUMEN}

Remoción de estiércol por escarabajos estercoleros (Coleoptera: Scarabaeinae) y uso de lactonas macrocíclicas en ranchos ganaderos de Yucatán, México. La expansión en el uso de lactonas macrocíclicas (LM) para el tratamiento de endo y ectoparásitos del ganado en las regiones tropicales puede reducir las poblaciones de escarabajos del estiércol, interrumpiendo así el proceso de eliminación de estiércol de ganado en los pastizales. Durante el período reproductivo (época de lluvias) de dos grupos funcionales de escarabajos coprófagos (paracópridos y telecópridos), se comparó la cantidad removida de estiércol usando trampas de exclusión cebadas con $500 \mathrm{~g}$ de estiércol de vaca libre de LM en dos ranchos donde se usan y en dos donde no se usan LM, en la península de Yucatán, México. En cada rancho se establecieron dos transectos (separados por 500 m) con seis trampas cada uno, las cuales estuvieron activas durante 24 horas. Después de este tiempo, todos los restos de estiércol en cada trampa se pesaron para registrar la remoción. Los resultados mostraron que las cantidades de remoción fueron similares en ranchos con y sin uso de LM. Los escarabajos estercoleros removieron $40.1 \%$ del peso total del excremento. Los paracópridos removieron 87.46 $\%$ y los telecópridos $12.54 \%$ del total de excremento removido. Los resultados indican que la función ecológica de los escarabajos estercoleros en los potreros estudiados no parece verse afectada por el uso de LM y que las especies paracórpidas remueven la mayor parte del excremento. Se requiere hacer más estudios en ambos tipos de ranchos, en los que se tome en cuenta la dinámica poblacional y el movimiento de las especies más importantes de la región, acoplados a estudios de laboratorio que evalúen el efecto de las LM sobre el éxito reproductivo, y de esta manera esclarecer el efecto de las LM sobre la función ecológica de este grupo de insectos tan importante para la sustentabilidad de los sistemas ganaderos.

Palabras clave: ivermectina, paracóprido, telecóprido, potrero.

\section{REFERENCES}

Andresen, E., \& Feer, F. (2005). The role of dung beetles as secondary seed dispersers and their effect on plant regeneration in tropical rain forest. In J. E. Lambert, P. E. Hulme, \& S. B. Vander-Wall (Eds.), Seed Fate: predation, dispersal and seedling establishment (pp. 331-349). Oxon: CABI International.

Basto-Estrella, G. S., Rodríguez-Vivas, R. I., Delfín-González, H., \& Reyes-Novelo, E. (2012). Escarabajos estercoleros (Coleoptera: Scarabaeinae) en ranchos de Yucatán, México. Revista Mexicana de Biodiversidad, 83, 380-386. 
Basto-Estrella, G. S., Rodríguez-Vivas, R. I., Delfín-González, H., \& Reyes-Novelo, E. (2014). Dung beetle (Coleoptera: Scarabaeinae) diversity and seasonality in response to macrocyclic lactones use at cattle ranches in the Mexican Neotropics. Insect Conservation and Diversity, 7, 73-81.

Bautista-Zúñiga, F., Batllori, E., Palacio, G., Ortiz, M., \& Castillo, M. (2005). Integración del conocimiento actual sobre los paisajes geomorfológicos de la Península de Yucatán. In F. Bautista-Zúñiga, \& G. Palacio (Eds.), Caracterización y manejo de los suelos de la Península de Yucatán. Implicaciones agropecuarias, forestales y ambientales (pp. 33-58). México: UAC-UADY-INE.

Canul-Ku, H. L., Rodríguez-Vivas, R. I., Torres-Acosta, J. F. J., Aguilar-Caballero, A. J., Pérez-Cogollo, L. C., \& Ojeda-Chi, M. M. (2012). Frequency of cattle herds with ivermectin resistant nematodes in the hot sub-humid tropics of Mexico. Veterinary Parasitology, 183, 292-298.

Chalcraft, D. R., \& Resetarits, W. J. (2003a). Mapping functional similarity on the basis of trait similarities. American Naturalist, 162, 390-402.

Chalcraft, D. R., \& Resetarits, W. J. (2003b). Predator identity and ecological impacts: functional redundancy or functional diversity? Ecology, 84, 2407-2418.

Dadour, I., Cook, D., \& Neesam, C. (1999). Dispersal of dung containing ivermectin in the field by Onthophagus taurus (Coleoptera: Scarabaeidae). Bulletin of Entomological Research, 89, 119-123.

Davis, A. L. V., \& Philips, T. K. (2005). Effect of deforestation on a southwest Ghana dung beetle assemblage (Coleoptera: Scarabaeidae) at the periphery of Ankasa conservation area. Environmental Entomology, 34, 1081-1088.

Errouissi, F., \& Lumaret, J. P. (2010). Field effects of faecal residues from ivermectin slow-release boluses on the attractiveness of cattle dung to dung beetles. Medical and Veterinary Entomology, 24, 433-440.

Floate, K. (2011). Arthropods in cattle dung on Canada's grasslands. In K. Floate (Ed.), Arthropods of Canadian Grasslands: Inhabitants of a Changing Landscape (pp. 71-88). Canada: Biological Survey of Canada.

Flota-Bañuelos, C., López-Collado, J., Vargas-Mendoza, M., Fajersson, P., González-Hernández, H., and Martínez-Morales, I. (2012). Efecto de la ivermectina en la dinámica espacio-temporal de escarabajos estercoleros en Veracruz, México. Tropical and Subtropical Agroecosystems, 15, 227-239.

Halffter, G., \& Edmonds, W. (1982). The nesting behavior of dung beetles (Scarabaeinae). An ecological and evolutive approach. México: Instituto de EcologíaMAB UNESCO.

Hanski, I., \& Cambefort, Y. (1991). Dung beetle ecology. New Jersey: Princeton University Press.

Lee, C. M., \& Wall, R. (2006). Cow-dung colonization and decomposition following insect exclusion. Bulletin of Entomological Research, 96, 315-322.

Littell, R. C., Milliken, G. A., Stroup, W. W., Wolfinger, R. D., \& Schabenberger, O. (2006). SAS for Mixed Models. Cary, USA: SAS Institute Inc.

Loreau, M. (2004). Does functional redundancy exist? Oikos, 104, 606-611.

Losey, J., \& Vaughan, M. (2006). The economic value of ecological services provided by insects. Bioscience, $56,311-323$.

Lumaret, J. P., Errouissi, F., Floate, K. D., Römbke, J., \& Wardhaugh, K. G. (2012). A Review on the toxicity and non-target effects of macrocyclic lactones in terrestrial and aquatic environments. Current Pharmaceutical Biotechnology, 13, 1004-1060.

Nichols, E., Spector, S., Louzada, J., Larsen, T., Amezquita, S., \& Favila, M. E. (2008). Ecological functions and ecosystem services provided by Scarabaeinae dung beetles. Biological Conservation, 141, 1461-1474.

Pérez-Cogollo, L. C., Rodríguez-Vivas, R. I., DelfínGonzález, H., Reyes-Novelo, E., \& Ojeda-Chi, M. M. (2015). Lethal and sublethal effects of ivermectin in Onthophagus landolti (Coleoptera: Scarabaeidae). Environmental Enthomology, 44, 1634-1640.

Ramírez-Cancino, L., \& Rivera-Lorca, J. A. (2010). La ganadería en el contexto de la biodiversidad. In R. Durán-García \& M. E. Méndez-González (Eds.), Biodiversidad y desarrollo humano en Yucatán (pp. 106-108). Mérida: CICY-PPDFMAM-CONABIO-SEDUMA.

Reyes-Novelo, E., Delfín-González, H., \& Morón-Ríos, M. A. (2007). Copro-necrophagous beetles (Coleoptera, Scarabaeidae, Scarabaeinae) diversity in an agroecosystem in Yucatan, Mexico. Revista de Biología Tropical, 55, 83-99. 
Slade, E. M., Mann, D. J., Villanueva, J. F., \& Lo, T. (2007). Experimental evidence for the effects of dung beetle functional group richness and composition on ecosystem function in a tropical forest. Journal of Animal Ecology, 76, 1094-1104.

Steinfeld, H., Gerber, P., Wassenaar, T., Castel, V., Rosales, M., \& Haan, C. (2006) Livestock's long shadow: environmental issues and options. Rome: FAO.

Verdú, J. R., Cortez, V., Ortiz, A. J., González-Rodríguez, E., Martinez-Pinna, J., Lumaret, J. P., Lobo, J. M., Numa, C., \& Sánchez-Piñero, F. (2015). Low doses of ivermectin cause sensory and locomotor disorders in dung beetles. Scientific Reports, 5, 13912.
Wall, R., \& Beynon, S. (2012). Area-wide impact of macrocyclic lactone parasiticides in cattle dung. Medical and Veterinary Entomology, 26, 1-8.

Wall, R., \& Strong, L. (1987). Environmental consequences of treating cattle with the anti-parasitic drug ivermectin. Nature, 327, 418-421.

Webb, L., Beaumont, D., Nager, R., \& McCracken, D. (2010). Field-scale dispersal of Aphodius dung beetles (Coleoptera: Scarabaeidae) in response to avermectin treatments on pastured cattle. Bulletin of Entomological Research, 100, 175-183. 